\title{
CHECK LIST OF SASKATCHEWAN MOTHS PART 14: FLOWER MOTHS
}

RONALD R. HOOPER, Royal Saskatchewan Museum, 2340 Albert Street, Regina, SK. S4P 3V7

Abbreviations used: $\mathrm{s}=$ south; $\mathrm{n}=$ north; $w=$ west; $e=$ east; $D A=$ Department of Agriculture collection (Saskatoon); CNC = the only Saskatchewan records that we know of are in the Canadian National Collection in Ottawa. (Unless otherwise indicated, all the species are represented in the collection of the Royal Saskatchewan Museum, formerly called the Saskatchewan Museum of Natural History.) The species are arranged according to the Check List of the Lepidoptera of America North of Mexico (R.W. Hodges, 1983).

Flower Moths (Heliothinae) These moths are fairly small (most species are from 16-25 $\mathrm{mm}$ in wing expanse). A lot of the species have an angled band or patch inward from the middle of the fore-wing. They can often be found at flowers in the day- time. Their designs and colours often match the flowers on which they feed. Only a few of the species come readily to lights. The caterpillars feed on flowers, and later on the fruit or capsule. The Corn Worm is a pest on corn, and the Flax Bollworm on flax. This colourful subfamily of moths, however, is a beautiful addition to our fauna.

White-spotted Midget - Eutricopis nexilis Morr. - $\mathrm{s}$ Sask., $\mathrm{n}$ to Bjorkdale and Prince Albert.

Rose Budworm - Pyrrhia umbra (Hufn.) - Kamsack, Waskwei River (n of Hudson Bay), Aylsham, Saskatoon, and La Ronge.

Purple-lined Sallow - Pyrrhia experimens (Wlk.) - central Sask., s to Fort Qu'Appelle, and $n$ to Cumberland House, and Île-à-la Crosse.

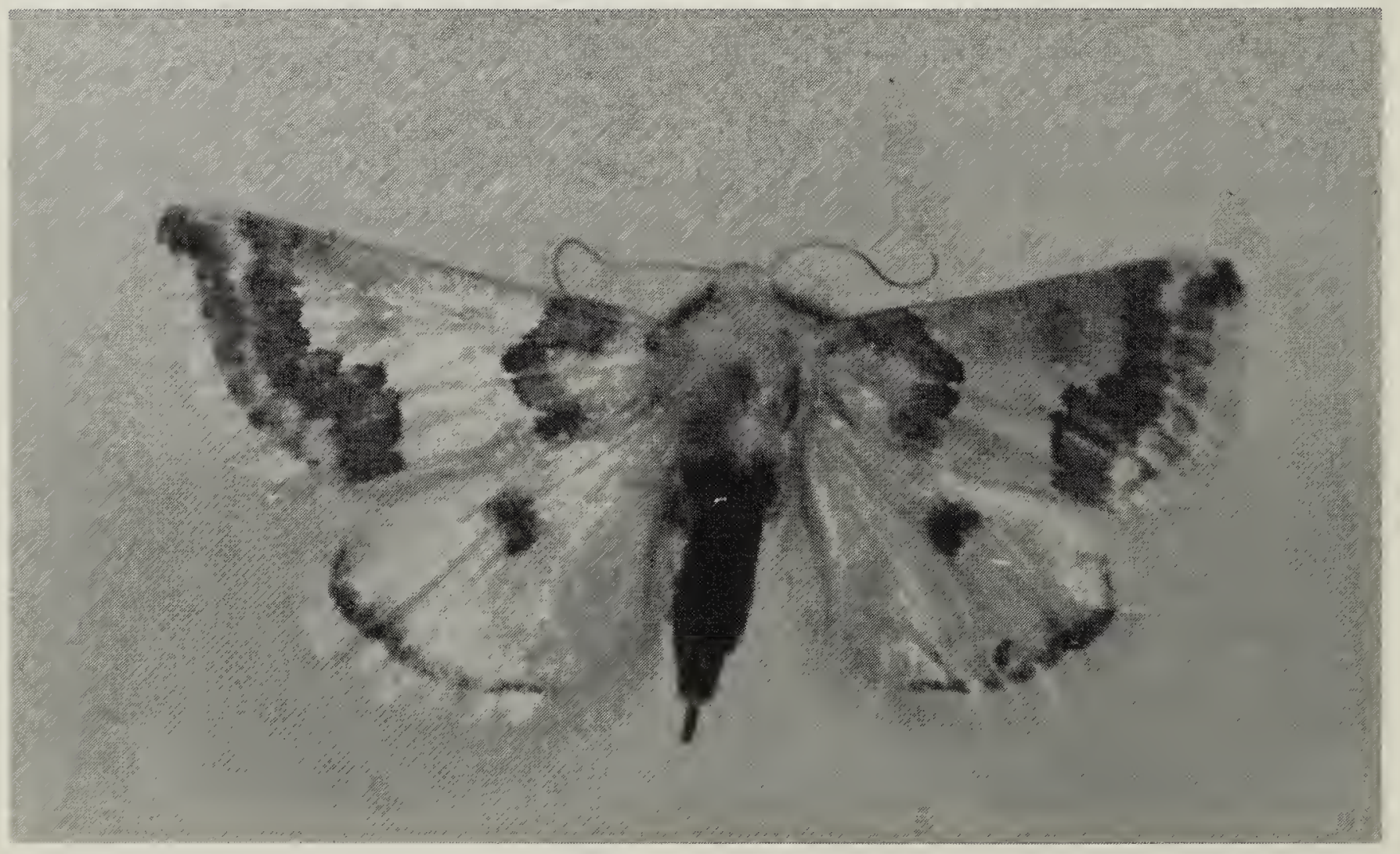




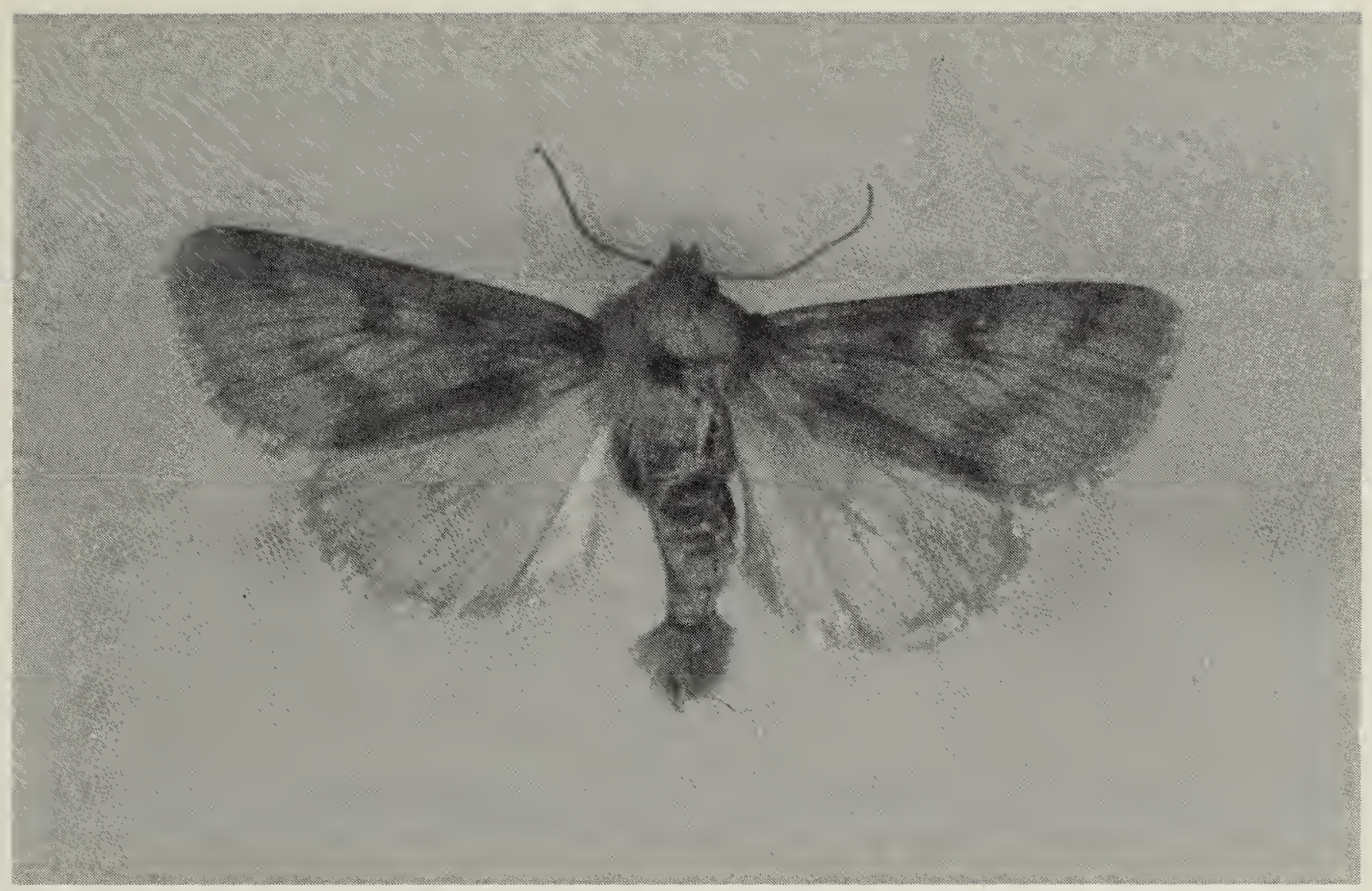

Corn Worm - Heliothis zea (Boddie) s Sask., $\mathrm{n}$ to Fort Qu'Appelle, and Saskatoon.

Spotted Buff Gem - Heliothis phloxiphagus G. \& R. - s Sask., $n$ to Aylsham.

Acesias Buff Gem - Heliothis acesias F. \& R. - Killdeer.

Flax Bollworm - Heliothis ononis (F.) - s Sask., $n$ to Saskatoon, Turtleford, and Frenchman Butte.

Oregon Gem - Heliothis oregonicus (Hy. Edw.) - Earl Grey, and Cypress Hills.

Boreal Gem - Heliothis borealis (Hamp.) - Davin Lake, Meadow Lake Prov. Park, Cypress Hills, and Rosefield (se of Val Marie).

Spotted Clover Moth - Protoschinia scutosa (F.) - Swift Current (DA).

Little Dark Gem - Schinia villosa (Grt.) - Lake Alma.

Verna Flower Moth - Schinia verna Hardwick - Saskatoon.

Persimilis Flower Moth - Schinia persimilis (Grt.) - Cypress Hills (CNC).

Bina Flower Moth - Schinia bina
(Gn.) - Bulyea, Buffalo Pound Provincial Park, Melfort, and Saskatoon.

Arcigera Flower Moth - Schinia arcigera (Gn.) - Roche Percee, Indian Head, and Moose Jaw.

Jaguar Flower Moth - Schinia jaguarina (Gn.) - Weyburn, Val Marie, and Swift Current.

Primrose Moth - Schinia florida (Gn.) - s Sask., $n$ to Aylsham, and Harlan (ne of Lloydminster).

Clouded Crimson - Schinia gaurae (J.E. Sm.) - Swift Current (CNC), Simmie (CNC), Millerdale ( $w$ of Dodsland) (DA).

Glorious Flower Moth - Schinia gloriosa (Stkr.) - Moose Jaw.

Mead's Flower Moth - Schinia meadi (Grt.) - s Sask., $\mathrm{n}$ to Saskatoon.

Acute-lined Flower Moth - Schinia acutilinea (Grt.) - sw Sask., n to Saskatoon, and e to Rockglen.

Silver-banded Gem - Schinia cumatilis (Grt.) - s Sask., $\mathrm{n}$ to Punnichy.

Dark-banded Flower Gem - Melaporphyria immortua (Grt.) - Harlan (ne of Lloydminster) (CNC). 


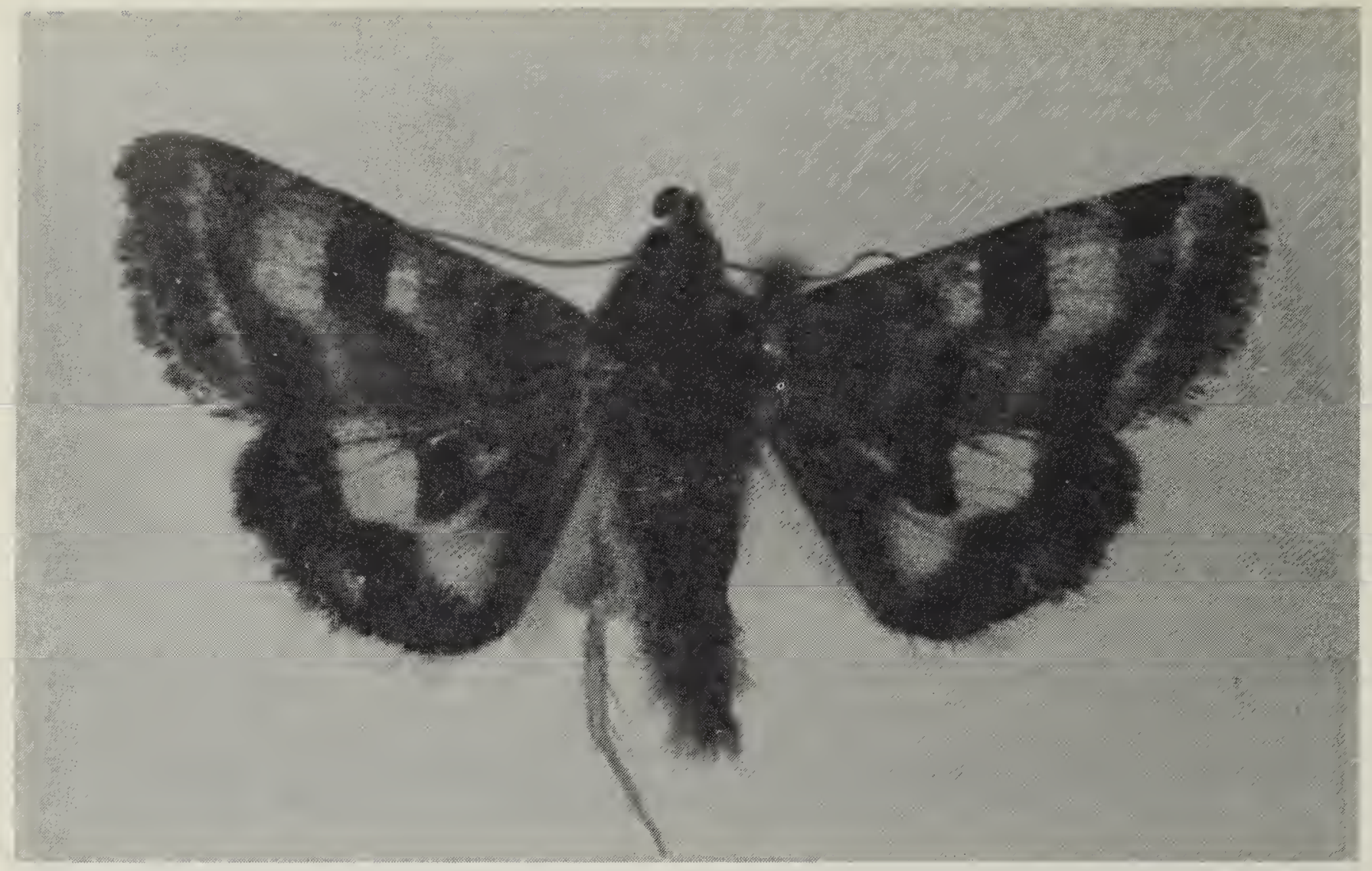

\section{Expected Species}

Olive-winged Gem - Schinia sueta martini Hdwk. - ne to the Sweetgrass Hills of Montana - should be watched for in the Cypress Hills, Saskatchewan.

Rose-coloured Flower Moth - Schinia roseitincta (Harv.) - $\mathrm{n}$ to Aweme, Manitoba.

Gold-edged Gem - Schinia avemensis (Dyar) - $\mathrm{n}$ to Onah, Aweme and Treesbank, Manitoba.

Thoreau's Flower Moth - Schinia thoreaui (G. \& R.) - nw to Glenlea, and Domain, Manitoba, and Malta, Montana.

Lead Plant Flower Moth - Schinia Iucens (Morr.) - $w$ to Aweme, Manitoba.

White Flower Moth - Schinia bimatris
(Harv.) - $\mathrm{n}$ to Aweme and Treesbank, Manitoba.

\section{References}

HARDWICK, D.F. 1958. Taxonomy, life history, and habits of the elliptoid-eyed species of Schinia (Lepidoptera: Noctuidae), with notes on the Heliothidinae. Can. Ent. Suppl. 6. 116 pp.

- 1970. A generic revision of the North American Heliothidinae (Lepidoptera: Noctuidae). Mem. Ent. Soc. Can. 73.59 pp.

-. 1983. A new species of Schinia (Noctuidae) from Manitoba and Saskatchewan with description of its life history. J. Lepid. Soc. 37:18-23.

- 1994. A review of the phloxiphaga group of the genus Heliothis (Noctuidae: Heliothentinae) with description of a new species. J. Lepid. Soc. 48:106-110. 